\title{
Combined Incubation of Cadmium, Docosahexaenoic and Eicosapentaenoic Acid Affecting the Oxidative Stress and Antioxidant Response in Human Hepatocytes In Vitro
}

\author{
P. LINHARTOVA ${ }^{1,2}$, I. GAZO ${ }^{1,3}$, S. SAMPELS ${ }^{1,2}$ \\ ${ }^{1}$ South Bohemian Research Center of Aquaculture and Biodiversity of Hydrocenoses, Faculty \\ of Fisheries and Protection of Waters, University of South Bohemia in České Budějovice, \\ České Budějovice, ${ }^{2}$ Institute of Aquaculture and Protection of Waters, České Budějovice, \\ ${ }^{3}$ Research Institute of Fish Culture and Hydrobiology, Vodňany, Czech Republic
}

Received November 2, 2015

Accepted March 11, 2016

\begin{abstract}
Summary
Human hepatocellular cells Hep G2 were used to investigate the effects of the intake of contaminated fish on oxidative stress. Uptake of heavy metal contaminated fish was mimicked by incubating the cells with a combination of cadmium chloride $\left(\mathrm{Cd}^{2+}\right)$ as possible contaminant and a combination of eicosapentaenoic acid (EPA) and docosahexaenoic acid (DHA) as important fatty acids (FA) specific for fish. The main aim of this study was to determine the effects of these co-incubations (FA, $\left(\mathrm{d}^{2+}\right)$ on lipid and protein oxidation. In addition we also evaluated the antioxidant response of the cells using two different methods (SOD and TAC). Pre-incubation with the chosen FA significantly reduced the oxidative stress caused by incubation with $\mathrm{Cd}^{2+}$. We measured an increased level of carbonyl proteins (CP) in the cells pre-incubated with bovine serum albumin (BSA) and post-incubated with $\mathrm{Cd}^{2+}$.
\end{abstract}

\section{Key words}

$\mathrm{EPA} \bullet \mathrm{DHA} \bullet$ Fish lipids $\bullet$ Heavy metal $\bullet$ ROS

\section{Corresponding author}

P. Linhartova, University of South Bohemia in České Budějovice, Faculty of Fisheries and Protection of Waters, South Bohemian Research Center of Aquaculture and Biodiversity of Hydrocenoses, Institute of Aquaculture and Protection of Waters, Husova tř. 458/102, 37005 České Budějovice, Czech Republic. E-mail: linhap01@frov.jcu.cz

\section{Introduction}

Pollution of the aquatic environment by heavy metals like cadmium poses a serious threat to the aquatic organisms including fish. In addition, subsequently and due to their lipophilic properties, heavy metals are bioaccumulated in the food chain and finally affect the consumers. The most anthropogenic sources of heavy metals are found in the industry, in addition to petroleum contamination and sewage disposal (Santos et al. 2005). $\mathrm{Cd}^{2+}$ is an environmental pollutant with a major intake via drinking water and food including seafood and fish. The main worldwide sources of cadmium are the phosphoric fertilizers used in crop farms (Mason 2002). $\mathrm{Cd}^{2+}$ concentrations in unpolluted natural waters are usually below $1 \mu \mathrm{g} / 1$.

As fish are an important source of essential omega-3 fatty acids (FA) and therefore an integral part of the human diet, it is important to evaluate the possible effects of the consumption of contaminated fish. Omega3 FA are the substrates for many hormone like substances that exert multiple beneficial effects in the human body, including anti-inflammatory actions by diminishing oxidative stress (Fukui et al. 2013). However, since the long chain polyunsaturated FA (PUFA) are also very prone to oxidation, this may lead to increased lipid peroxidation in the human body (Mori 2004). Several studies have shown that the accumulation of certain PUFA increase lipid peroxidation and the formation of lipid hydro peroxides in animals and humans (Cognault et al. 2000, Gago-Dominguez et al. 2005).

Cadmium $\left(\mathrm{Cd}^{2+}\right)$ is classified as a human carcinogen potent in a number of tissues, by International 
Agency for cancer research (IARC), (Waalkes 2003). $\mathrm{Cd}^{2+}$ acute intoxication leads to injuries of several organs, like liver, lungs or testes (Kasuya et al. 2000). Above that its chronic exposure is responsible to many human diseases as emphysema, end-stage renal failures, diabetic and renal dysfunction, deregulated blood pressure, osteoporosis, bone fractures or anemia (Jarup et al. 1998, Jin et al. 2004, Friberg et al. 1986). It also promotes the production of inflammatory cytokines (Maret and Moulis 2013). Important to know is that $\mathrm{Cd}$ has a high solubility and a huge bioaccumulation capacity in various aquatic species (Shreadah et al. 2015). However it also needs to be highlighted that despite enormous amount of research it is still not totally clear how $\mathrm{Cd}^{2+}$ induces cancer. There is clear evidence that multiple indirect mechanisms are involved in the tumor genesis, among which also oxidative stress has been mentioned by Hartwig (2010).

Oxidative stress can be defined as an imbalance between the systemic action of reactive oxygen species and the ability of biological systems to detoxify the reactive intermediates or repair the resulting damage in cells. Disturbances from normal redox conditions in cells can resort to toxic effects through the production of free radicals or peroxidases. These effects can damage all components inside of the cells, including proteins, lipids, or DNA (Sies 1995, 2007). It is known that $\mathrm{Cd}^{2+}$ can act as a catalyst in forming reactive oxygen species (ROS). It increases lipid peroxidation in addition it depletes antioxidants, glutathione and protein-bound sulfhydryl groups.

ROS is often involved in $\mathrm{Cd}^{2+}$ toxicology, as shown in different cell culture systems (Hart et al. 1999, He et al. 2008) and the acute toxicity of $\mathrm{Cd}^{2+}$ may result in advanced production of oxidative stress such as superoxide ion, hydrogen peroxide, and hydroxyl radicals (Bagchi et al. 1997, Liu and Jan 2000). Waisberg et al. (2003) also described that the expression of several stress response genes was induced by $\mathrm{Cd}^{2+}$. The same authors also provide an overview of the effects of cadmium on various enzymes of the antioxidant system and concluded that this together with the increased production of ROS might explain the increase in lipid peroxidation and DNA damage in cells exposed to $\mathrm{Cd}^{2+}$ (Waisberg et al. 2003).

$\mathrm{Cd}^{2+}$ can cause inflammation in the liver and the activation of Kupffer cells, which have shown to be an important source for $\mathrm{Cd}^{2+}$-induced inflammatory mediators of ROS such as IL-1 $\beta$, TNF- $\alpha$, IL-6, and IL-8. Several studies have shown a ROS production after exposure to $\mathrm{Cd}^{2+}$, led to a reduction in cellular antioxidants and lowered cellular defense against oxidative stress (Kayama et al. 1995, Yamano et al. 2000). In the study of Yano and Marcondes (2005) the concentrations higher than $7.5 \mu \mathrm{M} \mathrm{Cd}^{2+}$ caused oxidation of lipids in skeletal muscle cells (myoblasts).

Knowing the capacity of $\mathrm{Cd}^{2+}$ to induce $\mathrm{ROS}$ production and the fact that the nutritional valuable long chain n-3 PUFA are very prone to oxidation, the aim of the present study was to investigate whether a combined exposure would increase the oxidative stress in the cells and thereby also alter the possible positive effects of the consumption of fish if that is contaminated. We chose eicosapentaenoic acid (EPA) and docosahexaenoic acid (DHA) for a better understanding of the mechanism of nutritional important FA sensitive to oxidation. On the other hand, as DHA also has shown to have some anticarcinogenic properties. For this reason we suppose that these FA may be helpful in the development of effective cancer chemotherapeutic strategies involving their use as potential anticancer adjuvants.

\section{Methods}

\section{Caution}

Inorganic cadmium chloride $\left(\mathrm{CdCl}_{2}, \mathrm{Cd}^{2+}\right)$ is classified as a human carcinogen (IARC 1993). This chemical is hazardous, or potentially hazardous and should be handled with care.

\section{Chemicals}

EPA and DHA supplied from Biochrom and Sigma-Aldrich (Berlin, Germany), were diluted in extra pure $98 \%$ ethanol and bovine serum albumin (BSA) before transfer experiments. Hydrogen peroxide solution (30\%, Suprapurs) and nitric acid (65\%, Suprapur) were products of Merck (Darmstadt, Germany). Cadmium chloride was obtained from Aldrich, Germany. All other pro-analysis chemicals were obtained from SigmaAldrich (Steinheim, Germany) and Merck (Darmstadt, Germany). Trypsin, penicillin and streptomycin solutions were products of Sigma (Deisenhofen, Germany). Moreover, the culture dishes and the culture medium (MEM) for Hep G2 cells were obtained from Biochrom (Berlin, Germany).

\section{Cell culture}

Human hepatocellular cells (Hep G2, ATCC, No. HB-8065) were purchased from the American Type Culture Collection (ATCC, Manassas, VA, USA). 
Hep G2 cells were grown as a monolayer in culture dishes in Minimum Essential Medium Eagle (MEM) supplemented with fetal bovine serum (FBS), (10\%, $\mathrm{v} / \mathrm{v})$, non-essential amino acids $(1 \%, \mathrm{v} / \mathrm{v})$, glutamine $(2 \mathrm{mM})$, penicillin $(100 \mathrm{U} / \mathrm{ml})$ and streptomycin $(100 \mu \mathrm{g} / \mathrm{ml})$. The Hep G2 cultures were incubated at $37{ }^{\circ} \mathrm{C}$ with $5 \% \mathrm{CO}_{2}$ in air with $100 \%$ humidity. The amount of 1.5 million cells were seeded on $10 \mathrm{~cm}$ (in diameter) sterile Petri dishes in $10 \mathrm{ml}$ of sterile culture medium (MEM). Suspensions of Hep G2 cells were produced from confluent cultures using trypsin/EDTA solution. Before the transfer experiments, cells were three times thawed and sub-cultured to achieve a stable phenotype. For the transfer experiments, cells were seeded at a density of 1.5 Mio (million) per normal Petri dishes (10 cm in diameter). Seeded Hep G2 were cultured for $24 \mathrm{~h}$ and subsequently prepared for following preincubations and post-incubations with $\mathrm{FA}$ and $\mathrm{Cd}^{2+}$.

\section{EPA and DHA pre-incubations}

Before incubations fresh stock solutions of FA diluted in extra pure $98 \% \mathrm{EtOH}$ were defrosted. The BSA-FA complex was prepared as follows: BSA was dissolved in PBS (phosphate buffer saline). EPA and DHA respectively were dissolved in extra pure EtOH to a final volume of $50 \mu \mathrm{l}$ and $20 \mu \mathrm{l}$ of these solutions were then added to $1 \mathrm{ml}$ of a mixture of $0.1 \mathrm{M} \mathrm{NaOH}$ and BSA solution $(1 / 5 ; \mathrm{v} / \mathrm{v})$ each. The two solutions of FA were then combined and the $\mathrm{pH}$ was adjusted to 7.4 using $0.1 \mathrm{M} \mathrm{HCl}$. After testing concentrations from 1-50 $\mu \mathrm{M}$ EPA and from 2-100 $\mu \mathrm{M}$ DHA (preliminary results) we chose concentrations for pre-incubations of liver human cells with $5 \mu \mathrm{M} \mathrm{EPA}+10 \mu \mathrm{M}$ DHA for $24 \mathrm{~h}$ without changing MEM.

\section{$C d^{2+}$ post-incubations}

Fresh stock solutions of $\mathrm{Cd}^{2+}$ diluted in distilled sterile water $\left(\mathrm{ddH}_{2} \mathrm{O}\right)$ were prepared before the transfer experiments. Hep G2 cells were post-incubated for $24 \mathrm{~h}$ with $\mathrm{Cd}^{2+}$ stock solution with changing the cell culture medium (MEM). The range of $\mathrm{Cd}^{2+}$ concentrations were used from min. $1 \mu \mathrm{M}$ to $\max .5 \mu \mathrm{M}$.

\section{Confirmation of uptake of cadmium and FA into the cells}

The content of cadmium was earlier analyzed via ICP-MS as described earlier. Quantification was performed with an authentic standard (Linhartova and Sampels 2015).

Uptake of FA was also earlier confirmed as described in Linhartova and Sampels (2015).

\section{Pelleting of Hep G2 cells}

Cells were seeded in number of 1.5 million cells per Petri dish to $10 \mathrm{ml}$ MEM sterile culture medium. Seeded Hep G2 were cultured and treated with FA as a BSA-FA complex and $\mathrm{Cd}^{2+}$ for the appropriate times as described above. Subsequently cells were pelleted by trypsinising and centrifuging several times in PBS/FBS solution and frozen on $-80^{\circ} \mathrm{C}$.

\section{Oxidative stress and antioxidant response from pelleted} cells

Pellets were unfrozen on room temperature. Immediately after thawing, the tubes with pelleted cells were put on ice. For analyses of pellets, we dissolved each pellet in $500 \mu \mathrm{l}$ of extraction buffer (EB) and vortexed them well. Extraction buffer (EB) was prepared from phosphate buffer saline (PBS) containing $0.5 \mathrm{mM}$ ethylenediaminetetraacetic acid (EDTA) and $0.1 \mathrm{mM}$ phenylmethylsulfonyl fluoride (PMSF).

\section{Thiobarbituric acid reactive substances (TBARS)}

For evaluation of TBARS (Lushchak et al 2005, Lushchak 2011) each pellet (with FA/without FA and with/without $\mathrm{Cd}^{2+}, 1$ and $5 \mu \mathrm{M} \mathrm{Cd}^{2+}$ ) was dissolved in $500 \mu \mathrm{l}$ EB solution. Afterwards $100 \mu \mathrm{l}$ of sample dissolved in EB was taken for reaction process. $900 \mu \mathrm{l}$ of $10 \% \mathrm{TCA}$ in $0.2 \mathrm{M} \mathrm{H}_{3} \mathrm{PO}_{4}$ in total volume of $1 \mathrm{ml}$ of solution was added to the sample. After centrifuging, the supernatant (upper phase containing lipids) was transferred to clean tubes and the volume of supernatant was equally divided to get blank and reagent samples. TBA solution or water was added to reagent and blank samples. A standard curve was prepared using tetraethylpropane (TEP). Finally all samples were incubated for $30 \mathrm{~min}, 60^{\circ} \mathrm{C}$ on a plate mover and the absorbance at $530 \mathrm{~nm}$ was measured on plate reader (Invinite 200Pro, Tecan Group Ltd., Mannedorf, Switzerland).

\section{Carbonyl proteins $(C P)$}

$\mathrm{CP}$ as markers for protein oxidation were analyzed according to a method by (Lenz et al. 1989). $10 \%$ TCA in $0.2 \mathrm{M} \mathrm{H}_{3} \mathrm{PO}_{4}$ was added to each sample pellet and centrifuged $\left(5000 \mathrm{xg}, 10 \mathrm{~min}, \quad{ }^{\circ} \mathrm{C}\right)$, afterwards the supernatant was removed. Consequently EB was added and samples were vortexed well to resuspend the pellet. The obtained suspension was 
divided equally to two tubes for each sample. After centrifugation $\left(5000 \mathrm{xg}, 10 \mathrm{~min}, 4{ }^{\circ} \mathrm{C}\right)$ the supernatant was removed and 2,4-dinitrophenylhydrazine (10 $\mathrm{mM}$ DNPH) was added to one group of samples (CP sample), and $2 \mathrm{M} \mathrm{HCl}$ was pipetted to the second group (blank sample). Samples were vortexed to re-suspend the pellets. Finally samples were left at $22{ }^{\circ} \mathrm{C}$ in dark for $1 \mathrm{~h}$. Then samples were centrifuged $\left(5000 \mathrm{xg}, 10 \mathrm{~min}, 4{ }^{\circ} \mathrm{C}\right)$, supernatant was poured out and pellets were washed with ethanol-butyl acetate. After washing $6 \mathrm{M}$ guanidine- $\mathrm{HCl}$ was added, the pellets were homogenized and centrifuged to remove insoluble particles. At the end of this experiment the absorbance of supernatant was measured using plate reader (Invinite 200Pro, Tecan Group Ltd., Mannedorf, Switzerland) at $370 \mathrm{~nm}$ and the absorbance of total protein content was measured at $562 \mathrm{~nm}$. The CP was counted according to the formula:

$$
\begin{gathered}
\mathrm{CP}=\left(\left(\mathrm{A}_{370 \text { sample }}-\mathrm{A}_{370 \text { blank }}\right) / 0.011\right) / 220 \mu \mathrm{l}= \\
=\left(\left(\mathrm{A}_{370 \text { sample }}-\mathrm{A}_{370 \text { blank }}\right) / 0.011\right) / 0.22 \mathrm{ml} .
\end{gathered}
$$

\section{Superoxide dismutase (SOD)}

Inhibition activity of SOD was evaluated with a commercially available assay Kit (19 160 SOD determination kit, Sigma Aldrich, St. Louis) according to the manufacturers description. The absorbance of blanks and samples was measured using a plate reader at $450 \mathrm{~nm}$ and the Inhibition rate (\%) was counted according to formula:

Inhibition rate $\%=[($ average blank 1 - average blank 3$)-$ (average sample - average blank 2)] / (average blank 1 average blank 3 ).

\section{Total antioxidant capacity (TAC)}

TAC was analyzed using a commercial assay kit (Total Antioxidant Capacity Assay Kit, Sigma Aldrich, St. Louis) following the manufactures instructions. Pellets were dissolved in the same way was as described above for the previous kits. Supernatant was transferred from centrifuged samples to clean Eppendorf tubes and put on ice. The 96 well-plate was prepared and firstly Trolox standard $(0,0.2,0.4,0.67,0.8$ and $1 \mathrm{mM})$ was pipetted. Continually pellet samples were pipetted ( 3 times each sample per well). $\mathrm{Cu}^{2+}$ reagent solution from the kit was added to each well and mixed with the samples or standards. The plate was incubated in dark at $22{ }^{\circ} \mathrm{C}$ for $90 \mathrm{~min}$. The absorbance of samples at $570 \mathrm{~nm}$ was measured using a plate reader (Invinite 200Pro,
Tecan Group Ltd., Mannedorf, Switzerland) and the Trolox standard index was counted.

\section{Statistical analysis}

All analyses were conducted in triplicate. Normality and homogeneity of dispersions of studied values and comparisons were made by analysis of variance (two factorial ANOVA; factors: $\mathrm{Cd}^{2+}$ and FA) with subsequent post hoc Tukey's honest significant difference (HSD) test. The values were expressed as means \pm SD $\quad(n=3)$. All analyses were performed at a significance level of $p<0.05$ using STATISTICA 9.0 for Windows.

\section{Results}

\section{Cadmium and FA uptake}

Final cadmium content in the cells was related to the incubation concentration. At an incubation level of $1 \mu \mathrm{M} \mathrm{Cd} \mathrm{Cd}^{2+}$ and final content of $127.18 \pm 75$ and $138.45 \pm 8.27 \mu \mathrm{M} \mathrm{Cd}^{2+} / 10^{6}$ cells with and without FA (no significant difference) was reached, but significant differences were found between groups incubated with $5 \mu \mathrm{M} \mathrm{Cd}{ }^{2+}$ and with/without $\mathrm{FA}$, where final concentrations of $457.63 \pm 88.03$ and $365.84 \pm 76.93$ $\mu \mathrm{M} / 10^{6}$ cells, respectively were found. At the $5 \mu \mathrm{M} \mathrm{Cd}^{2+}$ co-incubation with FA seemed to increase $\mathrm{Cd}^{2+}$. Uptake of the FA into the cells was also evaluated. These results are further discussed in Linhartova and Sampels (2015).

\section{Oxidative stress indices}

Our results showed that, in the control group (0), the measured level of thiobarbituric acid reactive substances (TBARS) expressed as malondialdehyde was $8.93 \mathrm{nmol} / 10^{6}$ cells (Fig. 1). No significant differences were found for cells incubated with BSA or FA or the combination of $\mathrm{FA}$ and $\mathrm{Cd}^{2+}$ (Fig. 1). However, a significantly higher level of TBARS was observed in Hep G2 cells exposed to only $\mathrm{Cd}^{2+}$ at concentrations $1 \mu \mathrm{M}$ and above $\left(13.79 \mathrm{nmol} / 10^{6}\right.$ cells and $16.89 \mathrm{nmol} /$ $10^{6}$ cells for 1 and $5 \mu \mathrm{M} \mathrm{Cd}^{2+}$ respectively).

Similar results were found for protein oxidation (Fig. 2). Control and cells incubated with FA or with FA and $\mathrm{Cd}^{2+}$ showed no significant difference in $\mathrm{CP}$ while significant $(p<0.05)$ increased levels of $\mathrm{CP}$ was observed in group exposed to $1 \mu \mathrm{M} \mathrm{Cd}^{2+}(2.55 \mu \mathrm{M} / \mu \mathrm{g})$ and $5 \mu \mathrm{M}$ $\mathrm{Cd}^{2+}(4.25 \mu \mathrm{M} / \mu \mathrm{g})$. However, cells exposed to BSA reached the level of $\mathrm{CP}$ to $2.12 \mu \mathrm{M} / \mu \mathrm{g}$, which was an increase compare to control and FA groups. 


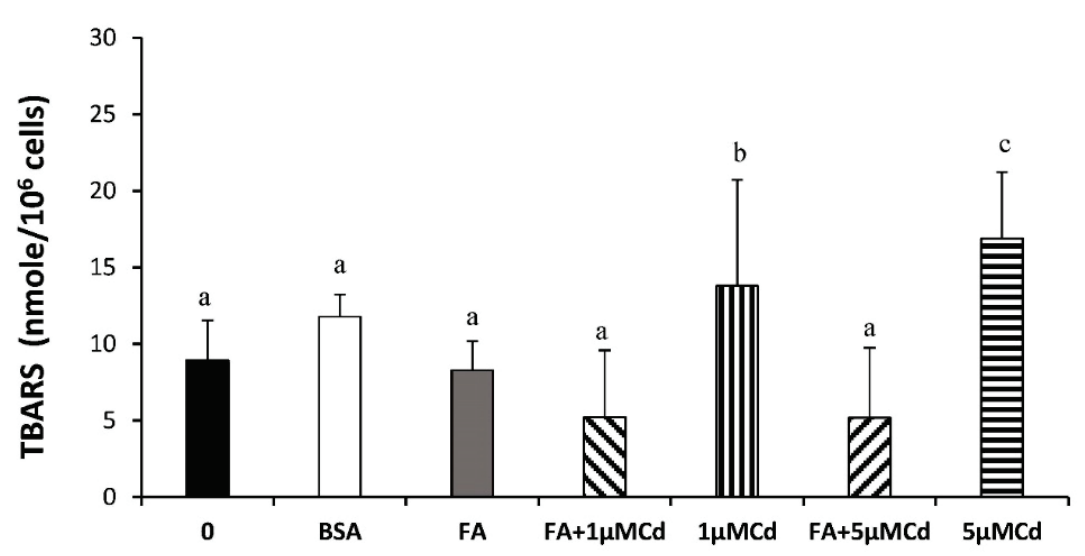

Fig. 1. Effects of $B S A, F A$ and $\mathrm{Cd}^{2+}$ on TBARS in Hep G2 cells. Data represent mean values $\pm S D, n=3$. Different letters indicate significant differences among samples (two factorial, ANOVA, FA and $\mathrm{Cd}^{2+}$, $p<0.05)$.

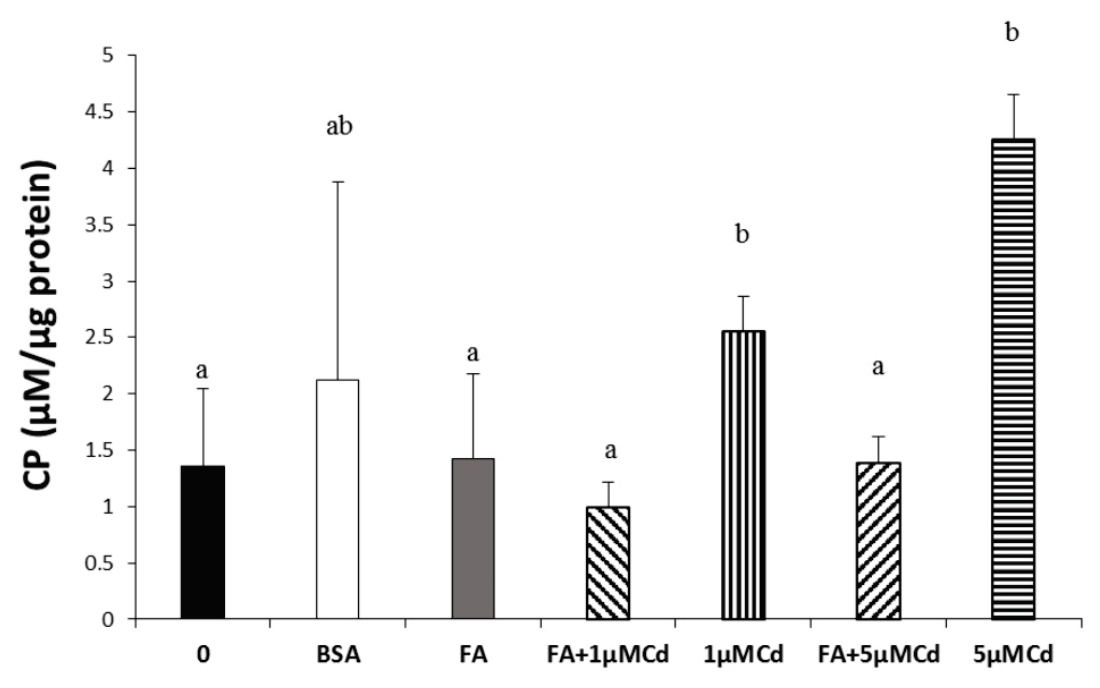

Fig. 2. Effects of $B S A, F A$ and $\mathrm{Cd}^{2+}$ on CP in Hep G2 cells. Data are presented as means $\pm S D, n=3$. Different letters indicate significant differences among samples (two factorial, ANOVA, FA and $\mathrm{Cd}^{2+}$, $p<0.05)$.

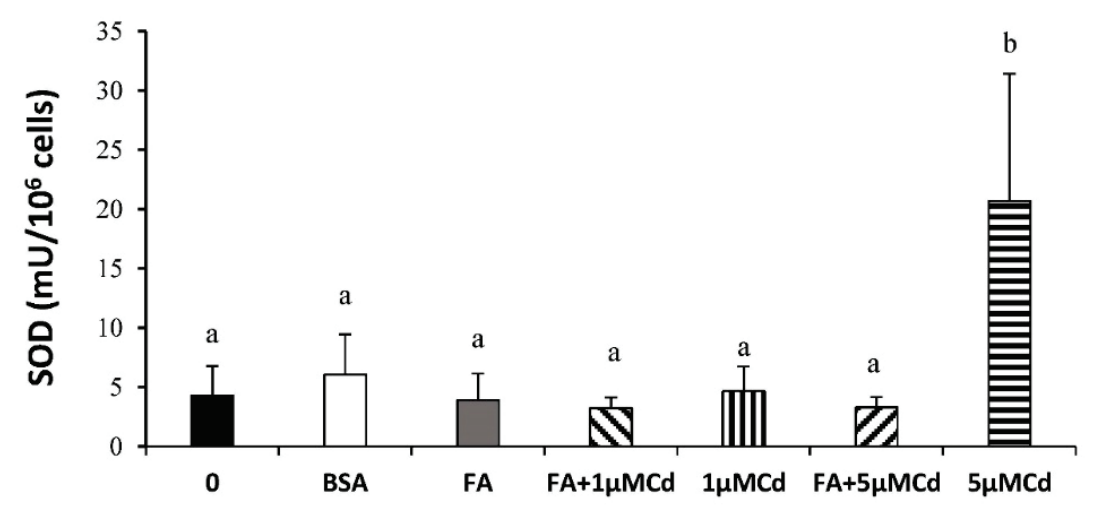

Fig. 3. Effects of $B S A, F A$ and $\mathrm{Cd}^{2+}$ on SOD activity in Hep G2 cells. Data represent mean values $\pm S D, n=3$. Different letters indicate significant differences among samples (two factorial, ANOVA, FA and $\mathrm{Cd}^{2+}$, $p<0.05$ ).

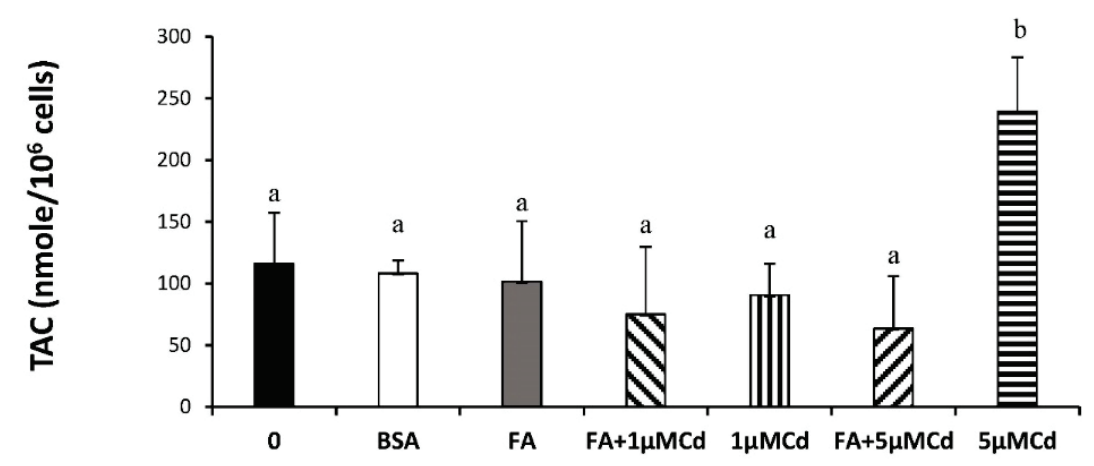

Fig. 4. Effects of $B S A, F A$ and $\mathrm{Cd}^{2+}$ on TAC activity in Hep G2 cells. Data are presented as means $\pm S D, n=3$. Different letters indicate significant differences among samples (two factorial, ANOVA, $\mathrm{FA}$ and $\mathrm{Cd}^{2+}$, $p<0.05)$. 


\section{Antioxidant responses}

The antioxidant activity was assessed by total SOD and TAC activity. There was no significant difference in SOD level between cells in control (0) and groups incubated with BSA and FA or with $1 \mu \mathrm{M} \mathrm{Cd}^{2+}$ (Fig. 3). However, the antioxidant response was significantly enhanced in cells exposed to $5 \mu \mathrm{M} \mathrm{Cd}^{2+}$ (20.68 mU/106 cells).

Similar results were found for TAC (Fig. 4). Significant increased TAC values were observed in the cells exposed to $5 \mu \mathrm{M} \mathrm{Cd}^{2+}$.

\section{Discussion}

The level of TBARS and $\mathrm{CP}$ were used as indicatives of the extent of lipid oxidation (LO) and protein oxidation (PO), respectively. $\mathrm{Cd}^{2+}$ alone in concentrations from $1 \mu \mathrm{M}$ induced oxidative stress. However, our results show a clear effect of the used FA in keeping both lipid and protein oxidation at levels comparable to control even when $\mathrm{Cd}^{2+}$ is present. In opposite incubation with only $\mathrm{Cd}^{2+}$ without the $\mathrm{FA}$ resulted in increased oxidation. This indicates to a protective effect of the chosen FA against oxidative stress caused by $\mathrm{Cd}^{2+}$. Also the results from the antioxidant response parameters point towards a protective effect of the FA, even if a significant increase of the antioxidant response was only visible at the highest used $\mathrm{Cd}^{2+}$ concentrations. However also here the co-incubation with FA resulted in similar low values of antioxidant response as in the non-exposed cells.

The increased CP values for the cells incubated with BSA only could be caused by the de facto higher protein availability in these cells from the free BSA used for incubation. In the cells incubated with FA as a BSA-FA complex, BSA was bound to the FA, which might result in a different reactivity and lower availability for oxidation.

Although the antioxidant system apparently responds to the increased ROS production, it seems that the antioxidant capacity of Hep G2 cells exposed to $\mathrm{Cd}^{2+}$ (without FA) is not sufficient to prevent cell damage. The antioxidant response, as shown by TAC and SOD assays, had significantly different values between groups treated with FA and with cadmium chloride only. The present study clearly demonstrated that Hep G2 cells are highly susceptible to oxidative stress induced by the environmental pollutant $\mathrm{Cd}^{2+}$.

In opposite to our results Qu et al. (2005) found that the exposure of rat liver cells to a low-dose $(1.0 \mu \mathrm{M})$ of $\mathrm{Cd}^{2+}$ after 28 weeks of continuous heavy metal exposure did not produce ROS. However this was a long term exposure, and already (Waisberg et al. 2003) showed in his review a possible adaptive effect against oxidative stress during long term exposure. On the other hand and in line with our results ROS production was evident after acute exposure of liver cells to higher doses of $\mathrm{Cd}$ (between 10-50 $\mu \mathrm{M} \mathrm{Cd}$ ), which are higher $\mathrm{Cd}^{2+}$ concentrations, but obviously human cells are more prone to oxidative stress than animal cells (Qu et al. 2005). This suggests that the effects of acute and chronic exposure to $\mathrm{Cd}^{2+}$ might differ and need a further evaluation.

Only few studies have investigated whether ROS are generated as the reaction to $\mathrm{Cd}^{2+}$ in Hep G2 cells and if this is responsible for inducing oxidative stress. The research of Lawal and Ellis (2010) showed a toxic effect of 5, 10 and $50 \mu \mathrm{M} \mathrm{Cd}^{2+}$, in three human different cell lines, (hepatocellular HepG2, astrocytoma (1321N1) and embryonic kidney (HEK 293) human cell lines). However significant increase of malondialdehyde (TBARS) and antioxidant enzymes activities were found in all three mentioned cell groups only after exposure to $50 \mu \mathrm{M} \mathrm{Cd}^{2+}$, which differs from our data, where we found ROS production already after exposure to ten time lower $\mathrm{Cd}^{2+}$ concentrations. More in line with our results, another study showed that already lower doses of $\mathrm{Cd}^{2+}$ $(10-20 \mu \mathrm{M})$ produced ROS in MCF-7 breast cancer cells (Matsuoka and Igisu 2001).

Many studies using different supplements like $\mathrm{N}$-acetyl cysteine, vitamin $\mathrm{E}$, vitamin $\mathrm{C}$, and selenium have shown that these substances can enhance body antioxidant machinery, by for example decreasing $\mathrm{Cd}^{2+}$-induced oxidative stress in kidney, liver, and testes, with improved cellular and tissue functions in many in vitro and in vivo studies (Shaikh et al. 1999, Sen Gupta et al. 2004, Zhou et al. 2009).

The results need to be confirmed in some kind of in vivo model, but our studies show that human cells in vitro assays may provide means of evaluating the effects of human environmental pollutants in relationship with nutrients as FA on the human body. This is necessary as usually the contaminants are not entering the human body alone but usually together with some food, which might result in some interaction, as shown in the present study.

\section{Conclusions}

Our results showed a positive effect of FA 
(5 $\mu \mathrm{M}$ EPA and $10 \mu \mathrm{M}$ DHA) against oxidative stress in the Hep G2 cells. It can be concluded, that antioxidant defense system, lipid peroxidation and oxidative damages are positively affected by the FA pre-incubations with the chosen FA in the determined doses. The combination of EPA and DHA seem to have a potential to decrease oxidative stress caused by $\mathrm{Cd}^{2+}$ in concentrations from $1 \mu \mathrm{M}$ in hepatocytes. Further research is needed to investigate the mechanism and the relationship between oxidative stress and FA uptake by liver cells.

\section{Conflict of Interest}

There is no conflict of interest.

\section{Acknowledgements}

The study was financially supported by the Ministry of Education, Youth and Sports of the Czech Republic - projects ,CENAKVA“[No.CZ.1.05/2.1.00/01.0024] and "CENAKVA II"[No. LO1205 under the NPU I program], by the Grant Agency of Czech Republic [GACR No. 13-01543S] and by the Grant Agency of the University of South Bohemia in Ceske Budejovice [GAJU No. 060/2016/Z]. The authors wish to thank Ing. Katerina Fulinova for her valuable help with sample preparation and analyses.

\begin{abstract}
Abbreviations
BSA: bovine serum albumin; BSA-FA: bovine serum albumin complex with fatty acids; $\mathrm{Cd}^{2+}$ : cadmium chloride; DHA: docosahexaenoic acid (C22:6 n-3); EPA: eicosapentaenoic acid (C20:5 n-3); FA: fatty acids; MEM: Minimum Essential Medium Eagle; PBS: phosphate saline buffer; PUFA: polyunsaturated fatty acids
\end{abstract}

\section{References}

BAGCHI D, VUCHETICH PJ, BAGCHI M, HASSOUN EA, TRAN MX, TANG L, STOHS SJ: Induction of oxidative stress by chronic administration of sodium dichromate and cadmium chloride to rats. Free Radic Biol Med 22: 471-478, 1997.

COGNAULT S, JOURDAN ML, GERMAIN E, PITAVY R, MOREL E, DURAND G, BOUGNOUX P, LHUILLERY C: Effect of an alpha-linolenic acid-rich diet on rat mammary tumor growth depends on the dietary oxidative status. Nutr Cancer 36: 33-41, 2000.

FRIBERG L, KJELLSTROM T, NORDBERG GF: Cadmium. In: Handbook on the Toxicology of Metals. L FRIBERG, GF NORDBERG, VB VOUK (eds), Elsevier, Oxford, 1986, pp 130-184.

FUKUI M, KANG KS, OKADA K, ZHU BT: EPA, an omega-3 fatty acid, induces apoptosis in human pancreatic cancer cells: role of ROS accumulation, caspase-8 activation, and autophagy induction. J Cell Biochem 114: 192-203, 2013.

GAGO-DOMINGUEZ M, CASTELAO JE, PIKE MC, SEVANIAN A, HAILE RW: Role of lipid peroxidation in the epidemiology and prevention of breast cancer. Cancer Epidemiol Biomarkers Prev 14: 2829-2839, 2005.

HART BA, LEE CH, SHUKLA GS, OSIER A, ENEMAN JD, CHIU JF: Characterization of cadmium-induced apoptosis in rat lung epithelial cells: evidence for the participation of oxidant stress. Toxicology 133: 43-58, 1999.

HARTWIG A: Mechanisms in cadmium-induced carcinogenicity: recent insights. Biometals 23: 951-960, 2010.

HE X, CHEN MG, MA Q: Activation of Nrf2 in defense against cadmium-induced oxidative stress. Chem Res Toxicol 21: 1375-1383, 2008.

IARC: Beryllium, cadmium, mercury, and exposures in the glass manufacturing industry. Working Group views and expert opinions. IARC Monogr Eval Carcinog Risks Hum 58: 1-415, 1993.

JARUP L, BERGLUND M, ELINDER C, NORDBERG G, VAHTER M: Health effects of cadmium exposure (a review of literature and a risk estimate). Scand J Work Environ Health 24: 1-52, 1998.

JIN T, KONG Q, YE T, WU X, NORDBERG GF: Renal dysfunction of cadmium-exposed workers residing in a cadmium-polluted environment. Biometals 17: 513-518, 2004.

KASUYA M, TERANISHI H, AOSHIMA K, KATOH T, HORIGUCHI H, MORIKAWA Y, NISHIJO M, IWATA K: Water pollution by cadmium and the onset of Itai-itai disease. Water Sci Technol 25: 149-156, 2000.

KAYAMA F, YOSHIDA T, ELWELL MR, LUSTER MI: Role of tumor necrosis factor- $\alpha$ in cadmium-induced hepatotoxicity. Toxicol Appl Pharmacol 131: 224-234, 1995. 
LAWAL AO, ELLIS E: Differential sensitivity and responsiveness of three human cell lines HepG2, 1321N1 and HEK 293 to cadmium. J Toxicol Sci 35: 465-478, 2010.

LENZ AG, COSTABEL U, SHALTIEL S, LEVINE RL: Determination of carbonyl groups in oxidatively modified proteins by reduction with tritiated sodium borohydride. Anal Biochem 177: 419-425, 1989.

LINHARTOVA P, SAMPELS S: Combined incubation of cadmium, docosahexaenoic and eicosapentaenoic acid results in increased uptake of cadmium and elevated docosapentaenoic acid content in hepatocytes in vitro. Lipids Health Dis 14: 156, 2015.

LIU F, JAN KY: DNA damage in arsenite- and cadmium-treated bovine aortic endothelial cells. Free Radic Biol Med 28: 55-63, 2000.

LUSHCHAK VI: Environmentally induced oxidative stress in aquatic animals. Aquat Toxicol 101: 13-30, 2011.

LUSHCHAK VI, BAGNYUKOVA TV, HUSAK VV, LUZHNA LI, LUSHCHAK OV, STOREY KB: Hyperoxia results in transient oxidative stress and an adaptive response by antioxidant enzymes in goldfish tissues. Int J Biochem Cell Biol 37: 1670-1680, 2005.

MARET W, MOULIS JM: The bioinorganic chemistry of cadmium in the context of its toxicity. Met Ions Life Sci 11: 1-29, 2013.

MASON CF: Biology of Freshwater Pollution. 4th ed. Pearson Education Limited, Harlow, 2002.

MATSUOKA M, IGISU H: Cadmium induces phosphorylation of p53 at serine 15 in MCF-7 cells. Biochem Biophys Res Commun 282: 1120-1125, 2001.

MORI TA: Effect of fish and fish oil-derived omega-3 fatty acids on lipid oxidation. Redox Rep 9: 193-197, 2004.

QU W, DIWAN BA, REECE JM, BORTNER CD, PI J, LIU J, WAALKES MP: Cadmium-induced malignant transformation in rat liver cells: role of aberrant oncogene expression and minimal role of oxidative stress. Int J Cancer 114: 346-355, 2005.

SANTOS IR, SILVA FILHO EV, SCHAEFER CE, ALBUQUERQUE FILHO MR, CAMPOS LS: Heavy metals contamination in coastal sediments and soils near the Brazilian Antarctic Station, King George Island. Mar Poll Bull 50: 85-194, 2005.

SEN GUPTA R, SEN GUPTA E, DHAKAL BK, THAKUR AR, AHNN J: Vitamin C and vitamin E protect the rat testes from cadmium-induced reactive oxygen species. Mol Cells 17: 132-139, 2004.

SHAIKH ZA, VU TT, ZAMAN K: Oxidative stress as a mechanism of chronic cadmium-induced hepatotoxicity and renal toxicity and protection by antioxidants. Toxicol Appl Pharmacol 154: 256-263, 1999.

SHREADAH M, FATTAH L, FAHMY M: Heavy metals in some fish species and bivalves from the Mediterranean coast of Egypt. J Environ Protect 6: 1-9, 2015.

SIES H: Strategies of antioxidant defense: relations to oxidative stress. In: Signalling Mechanisms - from Transcription Factors to Oxidative Stress. L PACKER, K WIRTZ (eds), Springer-Verlag, Berlin, 1995, pp 165-186.

SIES H: Total antioxidant capacity: appraisal of a concept. J Nutr 137: 1493-1495, 2007.

WAALKES MP: Cadmium carcinogenesis. Mutat Res 533: 107-120, 2003.

WAISBERG M, JOSEPH P, HALE B, BEYERSMANN D: Molecular and cellular mechanisms of cadmium carcinogenesis. Toxicology 192: 95-117, 2003.

YAMANO T, DECICCO LA, RIKANS LE: Attenuation of cadmium-induced liver injury in senescent male Fischer 344 rats: role of Kupffer cells and inflammatory cytokines. Toxicol Appl Pharmacol 162: 68-75, 2000.

YANO CL, MARCONDES MC: Cadmium chloride-induced oxidative stress in skeletal muscle cells in vitro. Free Radic Biol Med 39: 1378-1384, 2005.

ZHOU YJ, ZHANG SP, LIU CW, CAI YQ: The protection of selenium on ROS mediated-apoptosis by mitochondria dysfunction in cadmium-induced LLC-PK(1) cells. Vitro Toxicol 23: 288-294, 2009. 